\title{
IMPLEMENTASI DESAIN PEMBELAJARAN ASSURE MODEL PADA MATA PELAJARAN PAI DENGAN MATERI SEJARAH PERKEMBANGAN ILMU PENGETAHUAN UMAYYAH DAN ABBASIYAH
}

\author{
Tessa Qoriah Rasidi \\ Pasca Sarjana UIN Sunan Gunung Djati Bandung \\ Qoriah93@gmail.com
}

\begin{abstract}
The purpose of this study is to describe how the ASSURE learning design model is implemented. This is motivated by the needs of students in the material "the history of the growth of Umayyad and Abbasid science" which does not understand the history of the development of science in the Umayyad and Abbasid periods. So that the design of this learning exists to help understand the history of the growth of science during the Umayyad and the Abbasid period. ASSURE is a simple learning design that can be used to create a successful, effective, efficient and interesting learning. This learning model is practical and easy to use. The methodology used includes questionnaires, interviews and observations. The results of this study indicate that ASSURE learning design is quite effective in the history of the development of science during the Umayyad and Abbasid periods. Because students are required to explore thinking skills with the help of internet technology and learning together learning methods. With this also teachers and students are equally required to have thinking skills.
\end{abstract}

\section{Keyword:}

implementation, learning design, ASSURE, PAI, material history of the development of science umayyah and abbasiyah

\begin{abstract}
Abstrak :Tujuan dari penelitian ini adalah untuk mendeskripsikan bagaimana implementasi desain pembelajaran ASSURE model. Hal ini dilatarbelakangi oleh kebutuhan siswa pada materi "sejarah pertumbuhan ilmu pengetahuan umayah dan abbasiyah" yang belum paham bagaimana sejarah perkembangan ilmu pengetahuan pada masa umayyah dan abbasiyah. Sehingga desain pembelajaran ini ada untuk membantu memahamkan sejarah pertumbuhan ilmu pengetahuan pada masa umayyah dan abbasiyah. ASSURE merupakan desain pembelajaran yang sederhana yang dapat digunakan untuk menciptakan sebuah pembelajaran sukses, efektif, efisien, dan menarik. Model pembelajaran ini bersifat praktis dan mudah untuk digunakan Metodologi yang digunakan di antaranya adalah angket, wawancara dan obsertvasi. Hasil penelitian ini menunjukkan bahwa desain pembelajaran ASSURE cukup efektif dalam sejarah perkembangan ilmu pengetahuan pada masa umayyah dan abbasiyah. Karena siswa dituntut untuk mengeksplore kemampuan berpikir dengan bantuan teknologi internet dan metode pembelajaran learning together. Dengan ini juga guru dan siswa sama-sama dituntut untuk memiliki keterampilan berpikir.
\end{abstract}

Kata Kunci :

implementasi, desain pembelajaran, ASSURE, PAI, materi sejarah perkembangan ilmu umayyah dan abbasiyah

\section{PENDAHULUAN}

Aktivitas pembelajaran perlu dirancang sebelumnya agar dapat memeberikan hasil yang diharapkan. Upaya untuk merancang aktivitas pembelajaran disebut dengan istilah desain pembelajaran (Sharon, 2012, h. 214). Menurut Gagnon dan Collay dalam Benny istilah desain mempunyai makna adanya suatu kesuluruhan, struktur, kerangka, atau outline, dan urutan atau sistematika kegiatan. Mendesain aktivitas pembelajaran 
dapat diartikan sebagai upaya untuk membuat aktivitas pembelajaran menjadi terstruktur dan sistematis.

Merancang aktivitas pembelajaran perlu mengetahui tujuan yang akan dicapai, kompetensi yang perlu dimiliki oleh siswa yang belajar. Untuk mencapai suatu tujuan pembelajaran memerlukan sebuah kendaraan. Dalam konteks pembelajaran, kendaraan yang digunakan adalah metode, media, dan materi pembelajaran yang diperlukan untuk membantu siswa dalam mencapai kompetensi yang diinginkan.

Beberapa desain pembelajaran telah banyak dikemukakan oleh para ahli. Namun dalam penelitian ini peneliti mengambil model desain pembelajaran ASSURE yang dikembangkan oleh Sharon Smaldino, Robert Henich, James Rusell dan Miichael Molenda dalam buku Instructional Technology and Media for Learning. Model desain pembelajaran ASSURE sesuai untuk digunakan dalam aktivitas pembelajaran yang berskala. Oleh karena itu, sebagai calon guru sangat penting untuk mengetahui berbagai model desain pembelajaran ASSURE.

Dalam penelitian ini akan menerapkan pembelajaran desain ASSURE untuk mata pelajaran PAI kelas VIII di SMP Muhammadiyah 8 Arjasari dengan materi sejarah pertumbuhan ilmu pengetahuan umayyah dan abbasiyah. Dengan tahapan desain pembelajaran ASSURE yaitu menganalisis karakteristik siswa Analyzer learner characteristic, menetapkan tujuan pembelajaran State performance objectives, memilih metode, media dan materi pelajaran Select methods, media, and materials, menggunakan teknologi, media, dan materi Utilize materials, mengaktifan keterlibatan siswa Requires learner participation, evaluasi dan revisi Evaluation and revision.

Desain pembelajaran ASSURE merupakan desain pembelajaran yang sederhana yang dapat digunakan untuk menciptakan sebuah pembelajaran sukses, efektif, efisien, dan menarik. Model pembelajaran ini bersifat praktis dan mudah untuk digunakan. Selain itu model ASSURE sesuai untuk digunakan dalam aktivitas pembelajaran yang berlangsung di dalam kelas maupun program pelatihan.

Desain pembelajaran ini merupakan singkatan dari komponen atau langkah penting yaitu, menganalisis karakteristik siswa Analyzer learner characteristic, menetapkan tujuan pembelajaran State performance objectives, memilih metode, media dan materi pelajaran Select methods, media, and materials, menggunakan teknologi, media, dan materi Utilize materials, media, teknology, mengaktifan keterlibatan siswa Requires learner participation, evaluasi dan revisi Evaluation and revision.

Desain pembelajaran ini lebih berorientasi kepada pemanfaatan media dan teknologi dalam menciptakan proses dan aktivitas pembelajaran yang diinginkan. Pemanfaatan desain pembelajaran ASSURE perlu dilakukan tahap demi tahap (sistematik) dan menyeluruh (holistik) agar dapat memberikan hasil yang optimal yaitu terciptanya pembelajaran sukses.

Tahapan dalam Model ASSURE 


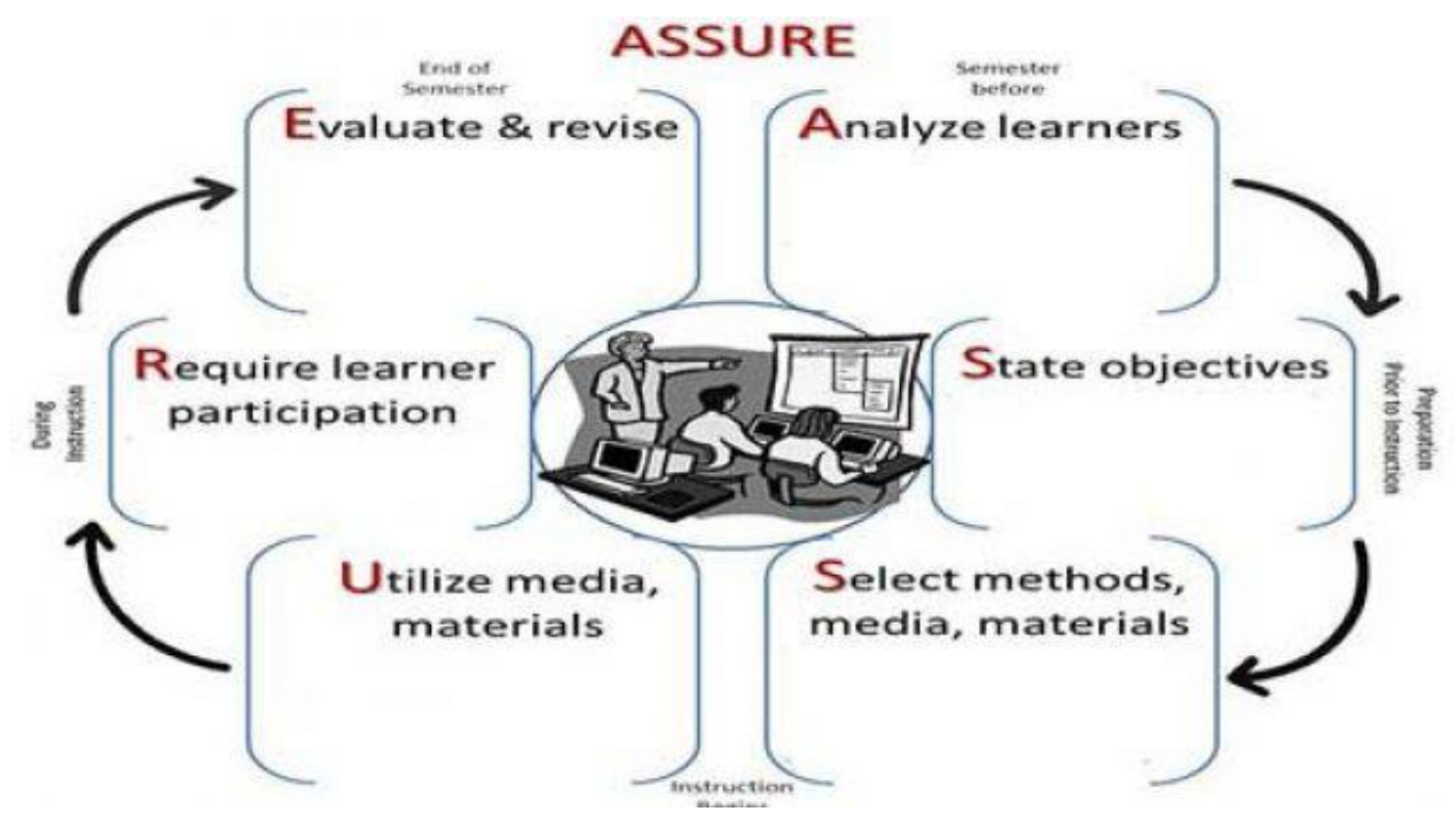

1. Analisis Karakter Siswa (Analyzer learner characteristic)

Langkah awal yang perlu dilakuakan dalam menerapkan desain pembelajaran ini dalah mengidentifikasi karakter siswa yang akan melekukan aktivitas pembelajaran. Tujuan utama para guru adalah memenuhi kebutuhan unik setiap siswa sehingga mereka bisa mencapai tingkat belajar yang maksimum. Deasin pembelajaran ASSURE memberikan pendekatan yang sistematis untuk menganalisis karakteristik para siswa yang memengaruhi kemampuan mereka untuk belajar.

Langkah yang pertama adalah mengidentifikasi karakteristik pebelajar. Media dan teknologi dikatakan efektif bila ada kesesuaian antara karakteristik siswa dengan metode, media, dan materi pembelajaran. Dalam praktik guru tidak mungkin menganalisis setiap siswa. Oleh karena itu, ada beberapa faktor yang penting untuk dipertimbangkan dalam membuat keputusan tentang penggunaan metode dan media analisis karakteristik siswa meliputi beberapa aspek penting, yaitu: karakteristik umum, kompetensi spesifik yang telah dimiliki siswa sebelumnya, gaya belajar atau learning style siswa, dan motivasi.

2. Menetapkan Tujuan Pembelajaran dan Kompetensi (State performance objectives)

Belajar pada hakikatnya adalah upaya dari individu untuk mencapai kompetensi yang diharapkan. Kompetensi dalam hal ini dapat dimaknai sebagai seperangkat tindakan cerdas yang dilakukan untuk menyelesaikan tugas atau pekerjaan spesifik. Dalam sebuah kompetensi terdapat beberapa aspek penting yang merupakan hasil atau output dari proses belajar. Kompetensi juga dapat dikatakan sebagai hasil dari proses pembelajaran.

Ada lima aspek kemampuan yang merupakan hasil dari belajar individu, yaitu: informasi verbal, keterampilan psikomotorik, sikap, keterampialn intelektual, dan strategi kognitif. 
Informasi verbal adalah kemampuan yang diperlukan untuk menyediakan respon lisan dan tertulis terhadap stimulus. Contoh kemampuan verbal ini adalah mengidentifikasi, menyusun daftar, menyebutkan, dan menjelaskan.

Keterampialn psikomotorik diartiakn sebagai pelaksanaan atau eksekusi suatu tindakan untuk mencapai hasil tujaun tertentu. Kemampuan psikomotorik dalam aktivitas melibatkan aktivitas berupa tindakan yang bersifat fisik dan penggunaan otot untuk melakukan suatu tindakan yang bertujuan. Tindakan yang terlihat dalam keterampialn psikomotorik pada dasarnya tidak hanya berupa tindakan fisik semata, tetapi melibatkan tindakan mental yang ada di dalamnya.

Sikap atau attitude yaitu kondisi internal yang memengaruhi pilihan individu dalam melakukan suatu tindakan. Sikap menujukkan adanya kecenderungan atau pilihan yang dimiliki oleh seseorang untuk melakukan suatu tindakan.

Keterampilan intelektual adalah keterampilan yang diperlukan oleh siswa untuk melakukan aktivitas kognitif yang bersifat unik. Keterampialn intelektual melibatkan kemampuan dalam menganalisa dan memodifikasi simbol-simbol kognitif atau informasi. Kemampuan pada ranah ini membuat siswa dapat menyusun klasifikasi benda berdasarkan label dan karakteristiknya.

Strategi kognitif merupakan kompetensi yang paling tinggi dari taksonomi yang dikemukakan oleh Gagne. Kompetensi ini berupa kemampuan metakognitif yang diperlihatkan dalam bentuk kemampuan berpikir tentang proses berpikir dan belajar bagaimana belajar. Contoh dari kompetensi beruap strategi kognitif adalah bagaimana seseorang membuat aktivitas belajar menjadi lebih efektif dan efisien.

3. Memilih Strategi, Teknologi, Media, dan Material (Select methods, media, and materials)

Langkah selanjutnya dalam menyusun mata pelajaran yang efektif yang mendukung pembelajaran melalui penggunaan teknolgi dan media yang sesuai adaah pemilihan strategi, teknlogi, media pengajaran, dan material mata pelajaran secara sistemtis. Panduan untuk melengkapi setiap aspek dalam proses pemilihan dibahas dalam bagian-bagiannya.

a. Memilih Strategi

Ketika mengidentifikasi strategi pengajaran untuk mata pelajaran harus memilih dua jenis: strategi yang berpusat pada guru dan strategi yang berpusat pada siswa. Strategi guru adalah kegiatan yang akan digunakan untuk mengajarkan mata pelajaran, menyajikan sebuah konsep dengan menampilkan sebuah video atau membaca sebuah kisah, atau menunjukkan bagaimana menkonjugasi sebuah kata kerja. Strategi tersebut harus kita gunakan ketika kita akan memilih berbagai metode pembelajaran. Metode pembelajaran merupakan cara yang digunakan oleh guru atau instruktur untuk menyampaikan isi atau materi pembelajaran secara spsifik, untuk membantu siswa dalam mencapai kompetensi yang diinginkan. Berdasarkan tujuan dan akivtas yang terdapat dialamnya, metode pembelajran dapat diklasifikasikan dalam bebrapa jenis yaitu: kooperatif, penemuan, 
pemecahan masalah, permainan, diskusi, latihan berulang, tutorial, demonstrasi, dan presentasi. Pertimbangan utama ketika memilih srategi pengajaran adalah bahwa strategi tersebut sebaiknya dapat membantu siswa mencapai standar dan tujuan. Selain itu pertimbangkanlah gaya belajar dan motivasi siswa. Tinjaulah model ARCS untuk melihat apakah strategi menarik perhatian siswa, dianggap relevan bagi kebutuhan mereka, untuk membangun rasa percaya diri mereka dan menghasilkan kepuasan dari apa yang mereka pelajari.

b. Memilih Teknologi dan Media

Teknologi dan media yang sesuai bisa menjadi tugas yang rumit mempertimbangkan kumpulan sumber daya yang tersedia, keberagaman para siswa dan tujuan belajar spesifik yang harus dicapai. Untuk menerangkan perbedaan-perbedaan teknlogi dan media, buku ini menyediakan rubrik seleksi. Rubrik seleksi menyediakan prosedur yang sistematis untuk menilai kualitas dari teknologi dan media yang spesifik, kriteria rubrik seleksi:

1) Selaras dengan standard, hasil, dan tujuan

2) Informasi yang terbaru dan akurat

3) Bahasa yang sesuai usia

4) Tingkat ketertarikan dan keterlibatan

5) Kualitas teknis

6) Mudah digunakan

7) Bebas bias

8) Panduan pengguna dan arahan

Ada beberpa jenis media pembelajaran yang dapat digunakan oleh guru atau instruktur, dan perancang program pembelajaran, yaitu: media cetak atau teks, media pameran atau display, media audio, gambar bergerak atau video, multimedia, media berbasis web atau internet.

4. Pemanfatan Media dan Materials (Utilize materials, media, technology)

Ketika telah memilih strategi dan jenjang teknologi dan media yang diperlukan dalam mata pelajaran, maka siap memilih materi yang diperlukan untuk mendukung pelaksanaan mata pelajaran. Langkah ini melibatkan tiga pilihan: memilih materi yang tersedia, mengubah materi yang ada, merancang materi baru. Materi pelajaran pada dasarnya terdiri dari beberapa komponen yaitu: konsep, fakta, prinsip, prosedur, keterampilan interpersonal, dan sikap.

5. Meminta Partisipasi Siswa (Requires learner participation) anda lakukan dengan tiap-tiap materi tersebut.

a. Menyiapkan Lingkungan

Dimana saja aktifitas belajar terjadi diruang kelas, laboratorium, pusat media fasilitas harus diatur untuk penggunaan teknologi, media, dan materi yang efektif. Beberapa media membutuhkan ruangan yang tepat, sumber tenaga listrik yang baik, dan akses terhadap saklar lampu. 
b. Menyiapkan Siswa

Penelitian mengenai belajar mengungkapkan bahwa apa yang dipelajari dari sebuah kegiatan sangat bergantung pada bagaiman para siswa dipersiapkan untuk mata pelajaran tersebut. Pemanasan tersebut dapat dilakukan dengan beberapa hal berikut:

1) Sebuah pengantar yang mempunyai tinjauan luas mengenai konten mata pelajaran

2) Alasan pemikian yang menjelaskan bagaiman mata pelajaran terkait dengan topik yang dipelajari

3) Motivasi untuk mengetahui, bagaimana mereka akan diuntungkan ketika menyimak pelajaran

4) Isyarat-isyarat yang mengarahkan perhatian pada aspek-aspek spesifik dari mata pelajaran

Ketika telah menyiapkan teknologi, media dan materi pembelajaran, maka kita harus dapat memanfaatkan bahan dan media pembelajaran tersebut. Kombinasi yang tepat dalam memanfaatkan metode dan media pembelajaran dapat membantu guru dan instruktur untuk menciptakan pembelajaran sukses. Ragam dasar media yang dapat digunakan untuk mendukung aktivitas pembelajaran yaitu: teks, suara, visual, gambar, kompuer multimedia, dan jaringan komputer.

6. Evaluasi dan Revisi (Evaluation and revision)

Evaluasi dan revisi meupakan komponen yang paling penting untuk mengembangkan kualitas pembelajaran (Ramayulis, 2012, h. 398).

a. Menilai hasil siswa

Pernyataan tentang hasil tujuan akan membantu untuk mengembangkan kriteria guna mengevaluasi unjuk kerja siswa baik secara individual maupun kelompok. Cara menilai pencapaian hasil belajar tergantung pada hakikat tujuan pembelajaran. Ada tujuan yang menuntut keterampilan kognitif, seperti membedakan kata sifat dengan kata keterangan, dan menyimpulkan sesuatu.

b. Menilai motode dan media

Evaluasi juga menilai metode dan media pembelajaran. Materi pembelajaran efektif, meningkatkan pembelajaran, penyajian membutuhkan waktu yang lebih banyak daripada apa yang seharusnya, dan analisis reaksi pebelajar pada metode pembelajaran dapat membantu untuk memperoleh data dengan cara yang halus. seperti, diskusi guru dengan siswa mengindikasikan bahwa siswa lebih suka belajar mandiri pada waktu presentasi kelompok. Percakapan dengan spesialis media akan memutuskan perhatian pada nilai khusus media dalam suatu unit pembelajaran, yang diperlukan untuk meningkatkan pembelajaran dimasa mendatang.

c. Revisi 
Langkah terakhir adalah melihat kembali hasil data evaluasi yang dikumpulkan. Melihat kesenjangan antara apa yang diharapkan dengan apa yang terjadi. Siswa mencapai suatu tujuan, reaksi siswa terhadap materi dan media yang disajikan, guru puas dengan nilai, guru seharusnya melekukan refleksi pelajaran dan tiap komponen. Buat catatan segera sebelum mengimplementasikan pelajaran lagi. Bila dari hasil data evaluasi menunjukkan ada kelemahan pada komponen tertentu, kembalilah pada bagan itu dengan merencanakan dan merevisinya.

\section{A. Materi Sejarah perkembangan ilmu pengetahuan pada masa bani umayyah dan bani Abbasiyyah}

\section{Perkembangan Pada Masa Bani Umayyah}

Dinasti Bani Umayyah didirikan oleh Muawiyah bin Abi Sufyan bin Harb bin Umayyah. Muawiyah dapat menduduki kursi kekuasaan dengan berbagai cara, siasat, dan tipu muslihat yang licik, bukan atas dasar demokrasi yang berdasarkan atas hasil pilihan umat Islam. Dengan demikian, berdirinya dinasti ini bukan berdasarkan hukum musyawarah.

Dinasti Bani Umayyah berdiri selama \pm 90 tahun (40-132 H/661-750 M), dengan Damaskus sebagai pusat pemerintahannya. Dinasti Umayyah sangat bersifat Arab Orientalis, artinya dalam segala hal dan segala bidang para pejabatnya berasal dari keturunan Arab murni, begitu pula dengan corak peradaban yang dihasilkan pada masa dinasti ini. Pada masa pemerintahan dinasti ini banyak kemajuan, perkembangan, dan perluasan daerah yang dicapai, terlebih pada masa pemerintahan Khalifah Walid bin Abdul Malik (86-96 H /705 $-715 \mathrm{M})$.

Pada masa awal pemerintahan Muawiyah bin Abi Sufyan ada usaha memperluas wilayah kekuasaan ke berbagai daerah, seperti ke India dengan mengutus Muhallab bin Abu Sufrah, dan usaha perluasan ke Barat ke daerah Byzantium di bawah pimpinan Yazid bin Muawiyah. Selain itu juga diadakan perluasan wilayah ke Afrika Utara. Juga mengerahkan kekuatannya untuk merebut pusatpusat kekuasaan di luar jazirah Arab, antara lain kota Konstantinopel.

Kemajuan-Kemajuan yang Dicapai :

a. Bani Umayyah berhasil memperluas daerah kekuasaan Islam ke berbagai penjuru dunia, seperti Spanyol, Afrika Utara, Suria, Palestina, Semenanjung Arabia, Irak, sebagian kecil Asia, Persia, Afghanistan, Pakistan, Rukhmenia, Uzbekistan dan Kirgis.

b. Islam memberikan pengaruh bagi kehidupan masyarakat luas. Sikap fanatik Arab sangat efektif dalam membangun bangsa Arab yang besar sekaligus menjadi kaum muslimin atau bangsa Islam. Setelah pada saat itu bangsa Arab merupakan prototipikal dari bangsa Islam sendiri.

c. Telah berkembang ilmu pengetahuan secara tersendiri dengan masingmasing tokoh spesialisnya. Antara lain, dalam Ilmu Qiro'at (7 qiro'at) yang terkenal yaitu Ibnu Katsir (120H), Ashim (127H), dan Ibnu Amr (118H). 
Ilmu Tafsir tokohnya ialah Ibnu Abbas $(68 \mathrm{H})$ dan muridnya Mujahid yangpertama kali menghimpun tafsir dalam sebuah suhuf, Ilmu Hadits dikumpulkan oleh Ibnu Syihab Az-Zuhri atas perintah Umar bin Abdul Aziz, tokohnya ialah Hasan Al-Basri (110H), Sa'id bin Musayyad, Rabi'ah ArRa'iy guru dari Imam Malik, Ibnu Abi Malikah, Sya'bi Abu Amir bin Syurahbil. Kemudian Ilmu Kimia dan Kedokteran, Ilmu Sejarah, Ilmu Nahwu, dan sebagainya.

d. Perkembangan dalam hal administrasi ketatanegaraan, seperti adanya Lembaga Peradilan (Qadha), Kitabat, Hajib, Barid dan sebagainya.

\section{Perkembangan Pada Masa Bani Abbasiyah}

Daulah Abbasiyah didirikan pada tahun 132H/750M, Abbasiyah merupakan kelanjutan dari pemerintahan daulah Umayyah yang telah hancur di Damaskus. Dinamakan Abbasiyah karena para pendiri dan penguasa dinasti ini merupakan keturunan Abbas, paman Nabi Muhammad SAW. Dinasti Abbasiyah di samping bercorak Arab murni, juga terpengaruh dengan corak pemikiran dan peradaban Persia, Romawi Timur, Msir, dan sebagainya. Juga dinasti Abbasiyah ini system politiknya lebih bersifat demokratis dari pada dinasti Umayyah yang Orientalis.

Pada masa pemerintahan Khalifah Al-Mahdi (158-169H/775-785M), dinasti Abbasiyah memperluas kekuasaan dan pengaruh Islam ke wilayah Timur Asia Tengah, dari perbatasan India hingga ke China. Saat itu umat Islam berhasil memasuki selat Bosporus, sehingga membuat Ratu Irene menyerah dan berjanji membayar upeti. Pada masa dinasti ini pula wilayah kekuasaan Islam sangat luas yang meliputi wilayah yang telah dikuasai Bani Umayyah, antara lain Hijjaz, Yaman Utara dan Selatan, Oman, Kuwait, Iran (Persia), Irak, Yordania, Palestina, Libanon, Mesir, Tunisia, Al-Jazair, Maroko, Spanyol, Afghanistan, dan Pakistan. Juga mengalami perluasan ke daerah Turki, wilayah-wilayah Armenia dan daerah sekitar Laut Kaspia, yang sekarang termasuk wilayah Rusia. Wilayah bagian Barat India dan Asia Tengah, serta wilayah perbatasan China sebelah Barat.

a. Kemajuan-Kemajuan dan Perkembangan yang Dicapai

Secara garis besar ada 2 faktor penyebab tumbuh dan berkembangnya peradaban Islam, yakni faktor internal dan faktor eksternal. Faktor internal berasal dari dalam ajaran Islam bahwa ajaran Islam yang bersumber pada Al-Qur'an dan Hadits, memiliki kekuatan yang luar biasa yang mampu memberikan motifasi bagi para pemeluknya untuk mengembangkan peradabannya. Sedangkan faktor eksternalnya, yaitu ajaran yang merupakan proses sejarah umat Islam di dalam kehidupannya yang dijiwai oleh nilainilai ajaran Islam. Faktor penyebab tersebut adalah semangat Islam, perkembangan organisasi ketatanegaraan, perkembangan ilmu pengetahuan, dan perluasan Islam.

b. Bentuk-Bentuk Peradaban Islam dan Tokoh-Tokohnya 
1) Kota-Kota Pusat Peradaban

Kota Baghdad, merupakan ibu kota negara kerajaan Abbasiyah yang didirikan oleh Khalifah Abu Ja'far Al-Mansur (754-775M) pada tahun 762 M. kota ini terletak di tepian sungai Tigris. Masa keemasan kota Baghdad terjadi pada masa pemerintahan Khalifah Harun Al-Rasyid (786-809 M), dan anaknya Al-Makmun (813-833M).

Kota Samarra, letaknya di sebelah timur sungai Tigris yang berjarak lebih kurang $60 \mathrm{~km}$ dari kota Baghdad. Di kota ini terdapat 17 istana mungil yang menjadi contoh seni bangunan Islam di kota-kota lain.7

2) Bangunan Tempat Pendidikan dan Tempat Peribadatan

a) Madrasah. Ada banyak madrasah, madrasah yang terkenal pada zaman itu adalah Nizamiyyah, yang didirikan oleh Nizam Al-Mulk, seorang perdana menteri pada tahun 456-486 H. Madrasah ini terdapat di banyak kota, antara lain di Baghdad, Isfahan, Nisabur, Basrah, Tabaristan, Hara, dan Musol.

b) Kuttab, yaitu sebagai lembaga pendidikan dasar dan menengah.

c) Majlis Muhadharah sebagai tempat pertemuan dan diskusi para ilmuan

d) Darul-Hikmah sebagai perpustakaan.

e) Masjid-masjid sebagai tempat beribadah dan sebagai tempat pendidikan tingkat tinggi dan takahsush. Di antara masjid yang terkenal adalah masjid Cordova, masjid Ibnu Touloun, masjid AlAzhar, dan sebagainya.

c. Bidang Ilmu Pengetahuan dan Tokoh-Tokohnya

1) Filsafat, para tokoh filosuf pada masa itu adalah : Abu Ishak Al- Kindi, Abu Nashr Al-Faraby, Ibnu Sina, Ibnu Bajah, Ibnu Thufail, Al-Ghazali, dan Ibnu Rusydi.

2) Ilmu Kedokteran : Abu Zakaria Yuhana bin Masiwaih, Sabur bin Sahal, Abu Zakaria Ar-Razy, dan Ibnu Sina.

3) Matematika, ahli matematika Islam yang terkenal ialah Al- Khawarizmi, seorang yang menemukan angka nol (0), sedangkan angka 1, 2, 3, 4, 5, 6, 7, 8, 9, 0, disebut juga "Angka Arab".

4) Farmasi dan Kimia, di antara para ahli farmasi dan kimia padamasa pemerintahan dinasti Abbasiyah adalah Ibnu Baithar.

5) Ilmu Perbintangan : Abu Mansur Al-Falaky, Jabir Al-Batany, dan Rayhan Al-Bairuny.

6) Ilmu Tafsir (Tafsir Al-Ma'tsur : Ibnu Jarir Ath-Thabari, Ibnu 'Athiyah Al-Andalusy, As-Sudai, Muqatil bin Sulaiman; dan Tafsir bir-Ra'yi : Abu Bakar Asam, Abu Muslim Muhammad bin Bahar Isfahany, dan Abu Yunus Abdussalam). 
7) Ilmu Hadits : Imam Abu Abdullah Muhammad bin Abi Al-Hasan AlBukhari (Imam Bukhari), Imam Abu Muslim bin Al-Hajjaj Al-Qushairy An-Naishbury (Imam Muslim), Ibnu Majah, Abu Dawud, An-Nasa'i.

8) Ilmu Kalam, di antara aliran ilmu kalam yang berkembang adalah Jabariyah, Qadariyah Mu'tazilah, dan Asy'ariyah. Para pelopornya adalah Jahm bin Sofwan, Ghilan Al-Dimisyqi, Wasil bin 'Atha', AlAsy'ari, dan Imam Ghazali.

9) Ilmu Bahasa : Sibawaih, Al-Kisai, dan Abu Zakaria Al-Farra.

\section{METODELOGI PENELITIAN}

Penelitian ini dilaksanakan di SMP Muhammadiyah 8 Arjasari pada tanggal 8-9 Januari 2016. Metode penelitian ini adalah kualitatif tipe deskriptif yaitu penelitian yang dilakukan dengan tujuan menggambarkan atau mendeskripsikan objek dan fenomena yang diteliti.

Untuk mengetahui dan memperoleh data yang dibutuhkan, maka peneliti menggunakan beberapa teknik pengumpulan data diataranya:

1. Observasi

Observasi dilakukan untuk memperoleh data dari lapangan dengan melalui pengamatan secara langsung terhadap objek penelitian. Data yang dimaksud antara lain proses pembelajaran desain ASSURE oleh tim peneliti di SMP Muhammadiyah 8 Arjasari.

2. Wawancara

Teknik ini dilakukan dengan cara melakukan dialog atau tanya jawab secara langsung dengan sejumlah responden, baik Kepala Sekolah, Guru, siswa, , serta pihak-pihak yang terkait dengan penelitian ini. Data yang dibutuhkan adalah masalah persepsi, sikap, dan respon para responden tehadap pembelajaran dengan Desain ASSURE yang di terapkan oleh tim peneliti.

3. Sumber Data

Sumber data dalam penelitian ini adalah subjek darimana data diperoleh. sumber data dalam penelitian ini terdiri dari data primer dan data sekunder. Data primer adalah data yang diperoleh dari subjek penelitian sesuai lingkup kebutuhan. Data sekunder adalah data yang diperoleh secara langsung dari objek yang diteliti maupun dari dokumen dan catatan lainnya yang menunjang dalam penelitian. Data primer dalam penelitian ini diperoleh dari responden-responden yang terdiri dari siswa SMP Muhammadiyah. Sedangkan data sekunder berasal dari data-data lain yang berkaitan dengan masalah penelitian. Data sekunder ini diperoleh dari buku-buku, teori, beberapa dokumen dan arsip-arsip yang menunjang penelitian. 


\section{TEMUAN DAN BAHASAN}

\section{A. Temuan}

Berdasarkan tahapan desain pembelajaran ASSURE adalah sebagai berikut.

1. Analisis Karakter Siswa

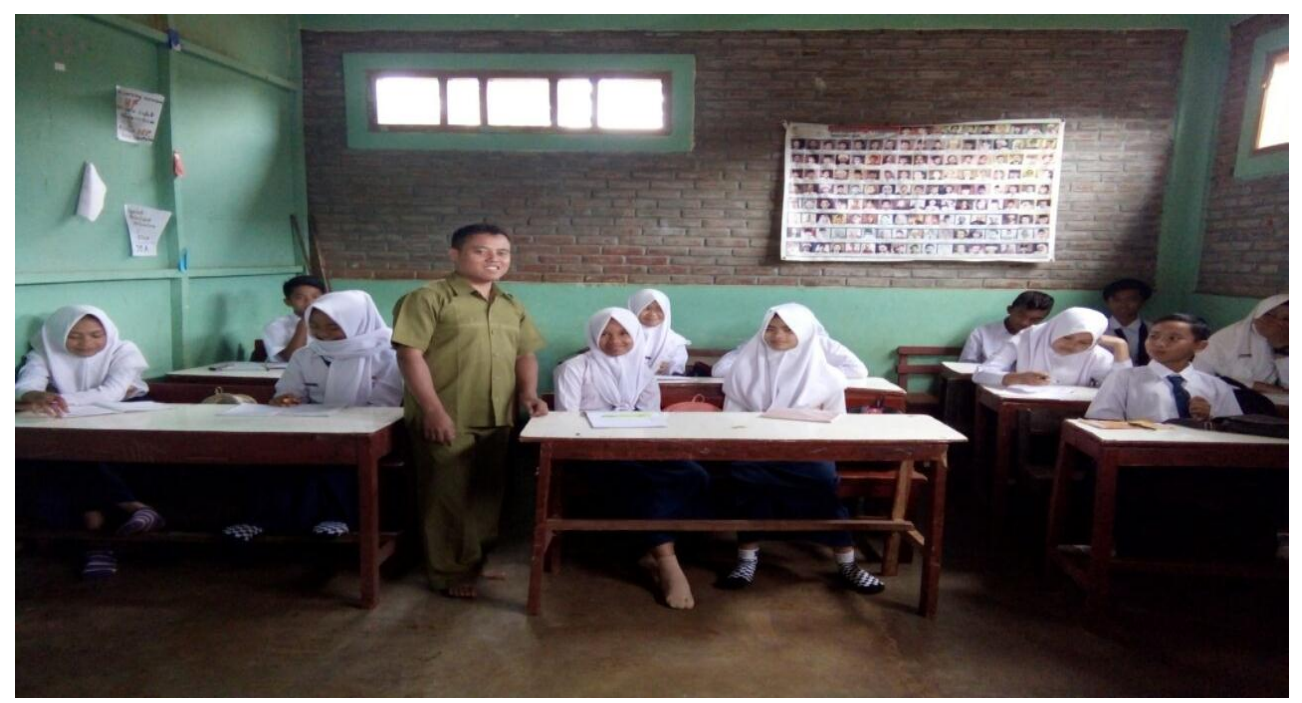

2. Menetapakan Tujuan Pembelajaran

a. Mendeskripsikan sejarah pertumbuhan ilmu pengetahuan sampai masa Umayah dan masa Abbasiyah

b. Menguraikan sejarah pertumbuhan ilmu pengetahuan sampai masa Umayah dan masa Abbasiyah untuk kehidupan sehari-hari.

3. Memilih Stategi Teknologi, Media, dan Material

a. Sejarah pertumbuhan ilmu pengetahuan sampai masa Umayah dan masa Abbasiyah

b. Sejarah pertumbuhan ilmu pengetahuan sampai masa Umayah dan masa Abbasiyah untuk kehidupan sehari-har

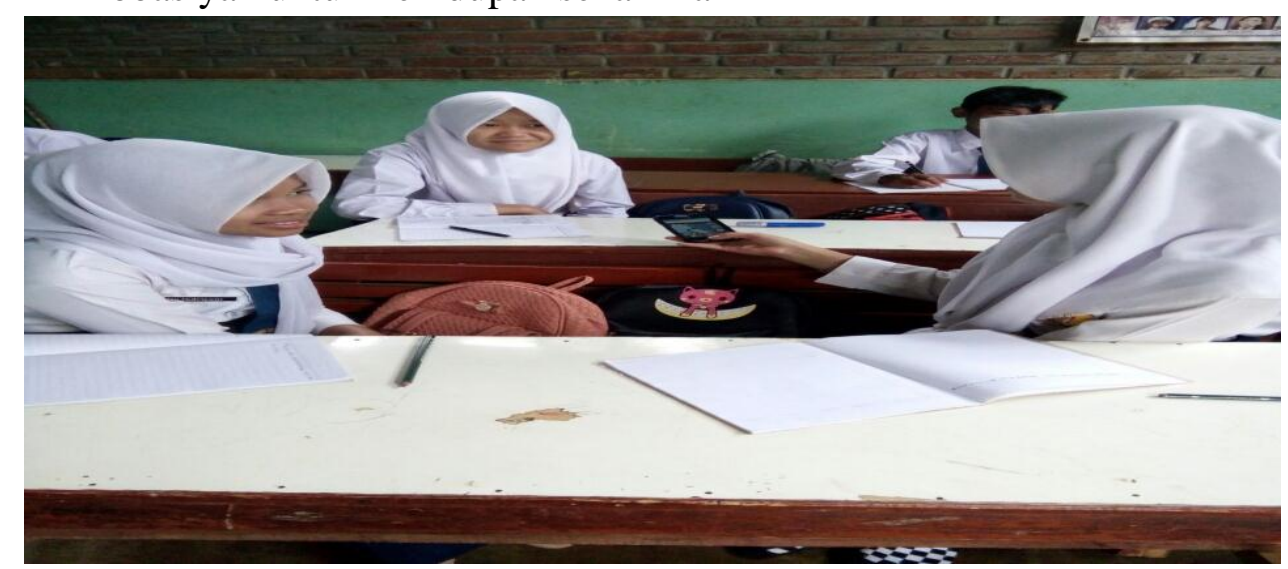




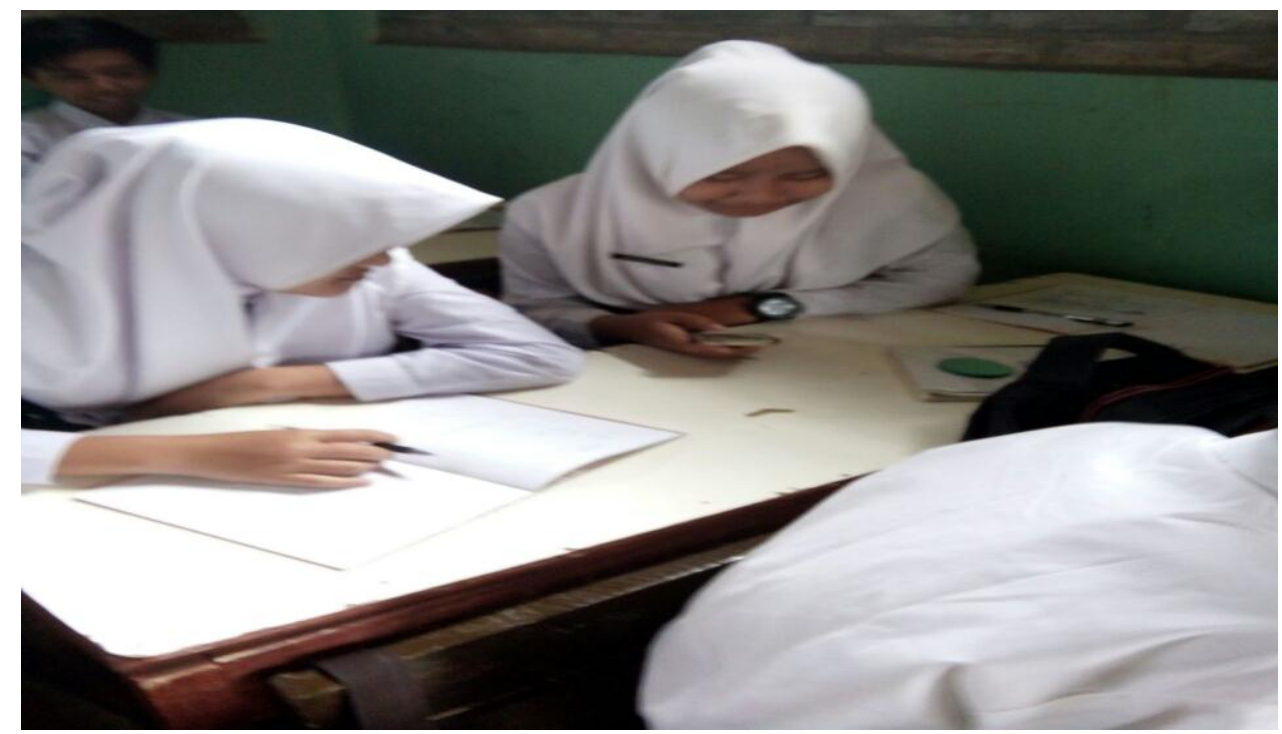

4. Pemanfatan Media dan Materials

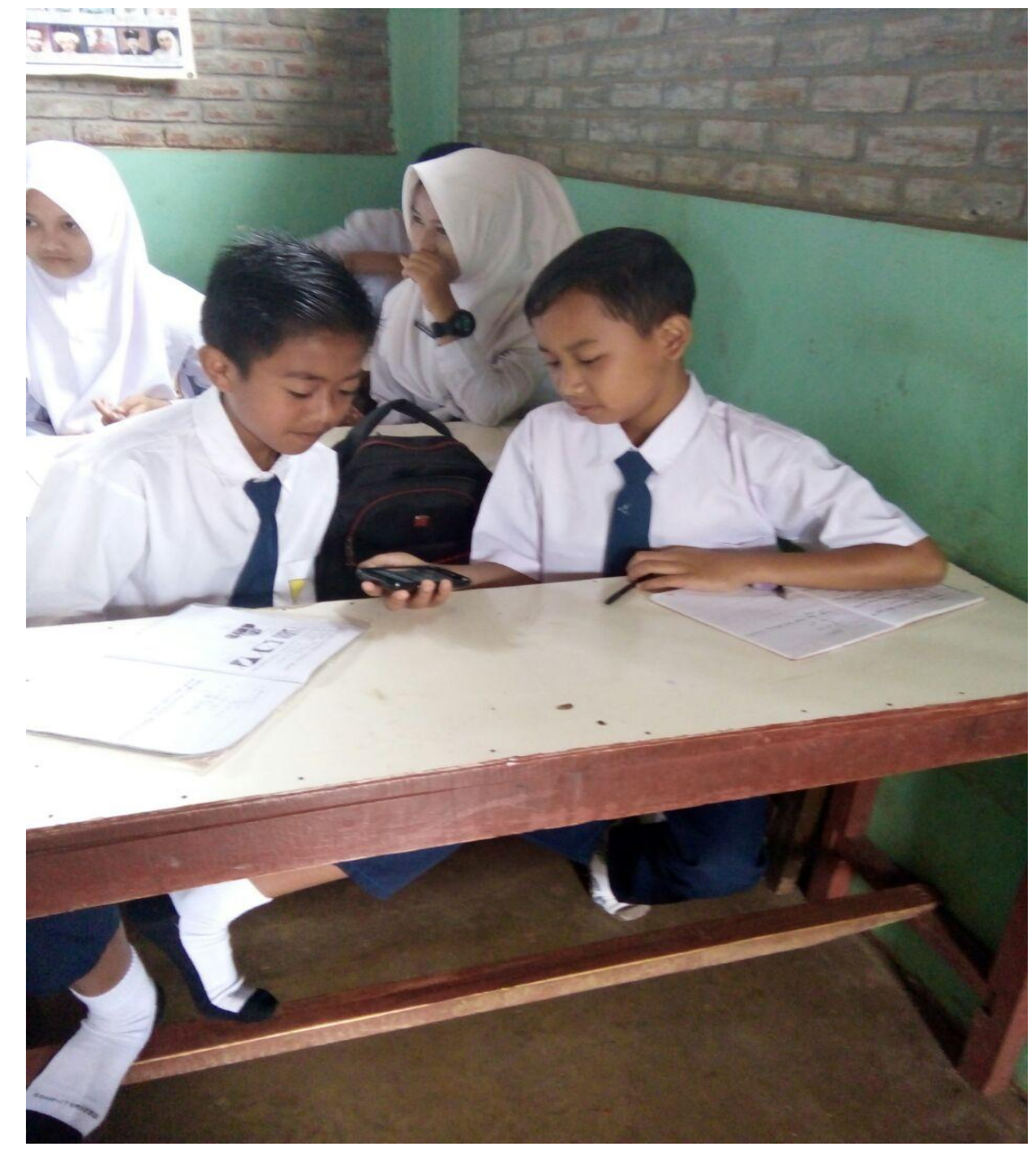


5. Meminta Partisipasi Siswa
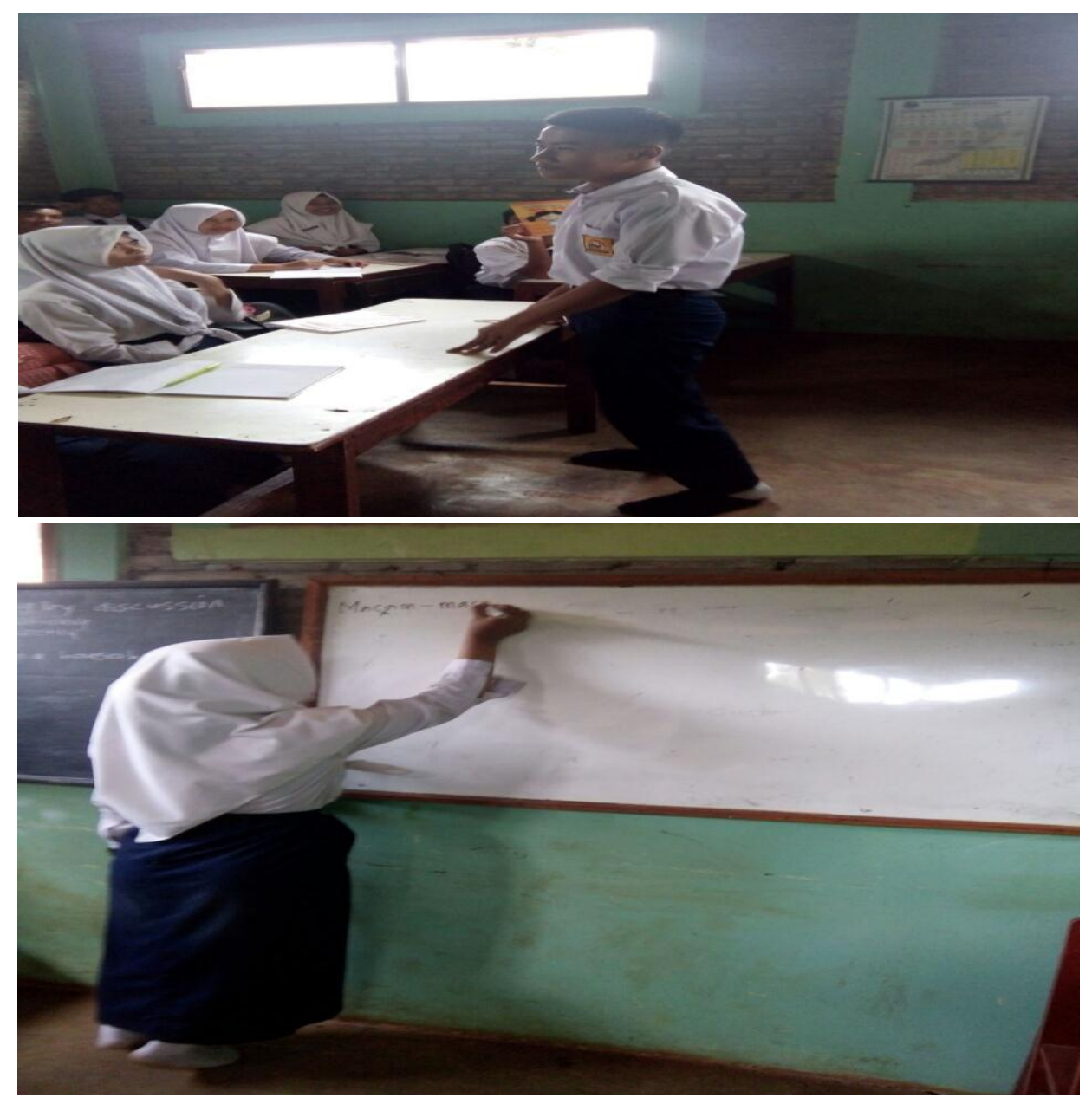

6. Evaluasi dan Revisi

\section{B. Pembahasan}

1. Analisis Karakter Siswa

a. Karakteristik umum

Siswa pada kelas VIII yang berusia sekitar 13-15 tahun, dalam tahapan operasional formal menurut teori perkembangan kognitif yang dikemukakan Piaget, dimana dalam tahap ini anak akan dapat seorang remaja telah memiliki kemampuan mengkoordinasikan baik secara simultan (serentak) maupun berurutan dua ragam kemampuan kognitif (Asri, 2015, h. 50). Dengan mengunakan discovery learning dengan metode discovery dan diskusi dianggap sesuai untuk perkembangan kognitif mereka.

b. Kemampuan awal

Pada pembelajaran sebelumnya siswa telah belajar tentang ketentuan makanan dan minuman yang halal dan haram berdasarkan Al-Quran dan 
Hadits kesulitan terhadap meghafal membedah ayat yang berkaitan dengan ketentuan makanan dan minuman yang halal dan haram berdasarkan Al-Quran dan Hadits. Contohnya menganalisis Q.S An-Nahl $: 114$.

c. Gaya Belajar

Sebagian besar siswa pada kelas ini memiliki gaya belajar visual dan kinestetik. Dimana ini terlihat dari pengamatan guru dalam pembelajaran sebelumnya.

d. Motivasi

Memotifasi siswa baik secara internal maupun eksternal seperti mendorong siswa untuk senantiasa semangat, diapresiasi hasil pencariannya, dan menjaga suasana hati siswa-siswa agar tetap nyaman.

2. Menetapkan Tujuan Pembelajaran dan Kompetensi

Ini telah dijelaskan secara rinci dalam kurikulum 2013 dalam bentuk kompetensi inti, kompetensi dasar, indikator dan tujuan pembelajaran.

a. Kompetensi Inti

KI.1 Menghargai dan menghayati ajaran agama yang dianutnya

KI.2 Menghargai dan menghayati perilaku jujur, disiplin, tanggungjawab, peduli (toleransi, gotong royong), santun, percaya diri dalam berinteraksi secara efektif dengan lingkungan sosial dan alam dalam jangkauan pergaulan dan keberadaannya..

KI.3 Memahami pengetahuan (faktual, konseptual dan procedural) berdasarkan rasa ingin tahunya tentang ilmu pengetahuan, teknologi, seni, budaya terkait fenomena dan kejadian tampak mata.

KI.4 Mengolah, menyaji, dan menalar dalam ranah konkret (menggunakan, mengurai, merangkai, memodifikasi, dan membuat, dan ranah abstrak (menulis, membaca, menghitung, menggambar, dan mengarang) sesuai dengan yang dipelajari di sekolah dan sumber lain yang sama dalam sudut pandang dan teori.

b. Kompetensi Dasar

1.3 Meyakini Nabi Muhammad SAW sebagai nabi akhir zaman

2.7 Menghargai perilaku semangat menumbuh kembangkan ilmu pengetahuan sebagai implementasi dari pemahaman

3.10 Memahami sejarah pertumbuhan ilmu pengetahuan sampai masa Umayah dan masa Abbasiyah

4.10 Merekonstruksi sejarah pertumbuhan ilmu pengetahuan sampai masa Umayah dan masa Abbasiyah untuk kehidupan sehari-hari

c. Indikator Pencapaian Kompetensi

1) Mendeskripsikan sejarah pertumbuhan ilmu pengetahuan sampai masa Umayah dan masa Abbasiyah

2) Menguraikan sejarah pertumbuhan ilmu pengetahuan sampai masa Umayah dan masa Abbasiyah untuk kehidupan sehari-hari 
d. Tujuan Pembelajaran

1) Mendeskripsikan sejarah pertumbuhan ilmu pengetahuan sampai masa Umayah dan masa Abbasiyah

2) Menguraikan sejarah pertumbuhan ilmu pengetahuan sampai masa Umayah dan masa Abbasiyah untuk kehidupan sehari-hari

3. Memilih Strategi, Teknologi, Media, dan Material

a. Memilih Strategi

Strategi yang dipada pada pembelajaran ini adalah menggunakan discovery learning dengan metode Learning Together dimana tiap kelompok menghasilkan sebuah deskripsi berupa skema mengenai hubungan antara pertumbuhan ilmu pengetahuan masa Umayah dengan Abbasiyah. Pada metode ini tidak ada kompetisi baik antar kelompok maupun antar anggota dalam kelompok. Jumlah anggota kelas adalah 25 siswa namun yang sekolah pada hari itu adalah 14 oarng. Anggota kelas akan dibagi dalam 2 kategori yaitu bani umayyah, dan bani abbasiyah. Setiap kategori terdapat 2 kelompok dengan jumlah masing-masing anggota kelompok adalah 6 samapai 7 orang. Dalam mempresentasikan hasil pengamatan tiap kelompok diberi waktu \pm 6 menit.

b. Memilih Teknologi

Teknologi yang dipilih pada pembelajaran ini adalah internet, dan handphone. Sudah tidak diragukan lagi kemampuan siswa dalam menggunakan alat-alat ini, guru berusaha mengintegrasikan teknologi internet. Dalam melakukan pengamatan siswa diminta untuk membuat deskripsi dan skema dari setiap item.

c. Memilih Materi

Materi Ajar yang digunakan pada pembelajaran ini adalah buku siswa dimana materi ajar telah terdapat didalamnya serta hasil pencarian di internet dan setiap kelompok yang akan dipresentasikan. Materi ajar telah tersedia pada buku siswa yang telah dimiliki oleh masing-masing siswa.

4. Pemanfatan Teknologi dan Media

a. Pemanfatan Teknologi

Teknologi yang gunakan adalah internet dan hanphone, karena internet dan hanphone yang siswa memiliki semua.

b. Pemanfatan Media

Dalam menggunakan media gambar atau skema sebagai media presentasi, dalam kegiatan persiapan presentasi, guru membimbing siswa bagaimana cara menggunakan gambar atau skema untuk mempresentasikan hasil pencarian mereka.

5. Meminta Partisipasi Siswa

Dalam pembelajaran ini siswa dilibatkan dalam menentukan sendiri objek pengamatan mereka, menggunakan handphone masing-masing, selain keterlibatan dalam kegiatan praktek, siswa juga terlibat dalam tanya jawab 
dan diskusi. Mereka mencari dengan handphone mereka masing-masing kelompok yang telah ditentukan yaitu kelompok Abbayiah dan Umayah.

6. Evaluasi dan Revisi

Dalam pembelajaran ini, guru mengevaluasi hasil belajar siswa dan pelaksanaan pemebelajaran hari ini. Untuk hasil belajar, guru menggunakan lembar pengamat dan rubrik untuk diskusi. Penilaian dilakukan secara individual dan kelompok. Secara individual, skor didapatkan dari tugas individu yang telah dikerjakan, dan partisipasi serta kontribusi individu dalam kelompok. Sedangkan penilaian kelompok diberikan melalui penghargaan (reward).

Untuk mengevaluasi pelaksanaan pembelajaran, guru mencocokkan kembali dengan rencana yang telah dibuat, apakah sesuai dengan alokasi waktu, strategi yang digunakan sudah tepat atau apakah media yang digunakan telah sesuai. Dengan evaluasi ini, guru bisa merevisi pembelajaran yang telah dijalankan sebagai referensi untuk pembelajaran yang akan datang di SMP Muhammadiyah 8 Arjasari yang perlu dievaluasi adalah aktivitas siswanya karena siswa-siswa yang pemalu sehingga ketika disuruh untuk mempresentasikan hasil temuannya saling tuduh menuduh, itu menjadi evaluasi untuk peneliti untuk memperhatikan analisis karakter siswa dari segi presentasi.

\section{SIMPULAN}

Berdasarkan hasil penelitian di atas dapat disimpulkan bahwa desain pembelajaran ASSURE dapat menjadi alternative desain pembelajaran khususnya di SMP Muhammadiyah 8 Arjasari, karena guru seacara utuh mempersiapkan pembelajan dengan analisis karakter siswa, menentukan tujuan dan kompetensi siswa, memilih teknologi, metode, materi, dan media, siswa memanfaatkan teknologi, guru dan siswa berpartisipasi dalam pembelajaran tersebut dan evaluasi untuk revisi untuk pembelajaran yang lebih baik.

\section{DAFTAR PUSTAKA}

Benny A Pribadi. 2011. Model ASSURE Untuk Mendesain Pembelajaran Sukses. Jakarta: Dian Rakyat.

C. Asri Budinigsih. 2015. Belajar dan Pembelajaran. Jakarta: Rineka Cipta. Ramayulis. 2012. Ilmu Pendidikan Islam. Jakarta: Kalam Mulia.

Sharon Smaldino. 2012. Instructional Technology and Media for Learning. Jakarta: Kencana.

Sri Anitah. 2008. Media Pembelajaran. Yogyakarta: Yuma Pustaka. 